\title{
Statistical Evaluation of Non-Agglomerating Coating for Granulated Natural Asphalt
}

\author{
Tjokorde Walmiki Samadhi, I Dewa Gede Arsa Putrawan, \\ Bambang Eko Prabowo \& Alinda Dwitawidi
}

Chemical Engineering Program, Bandung Institute of Technology

Labtek X Building, Jalan Ganesha 10, Bandung 40132

Email: twsamadhi@che.itb.ac.id

\begin{abstract}
Agglomeration of granulated Buton natural asphalt during storage is of major concern in its large-scale commercial application. This work develops a simple test method to evaluate the performance of agglomeration-resistant coating for granulated Buton asphalt, consisting of water-based polymeric primary coating and mineral-based secondary coating. The method uses a static load cell to measure the agglomerated granule count fraction under simulated storage conditions. A $2^{4-1}$ fractional factorial experiment with two replications is employed to evaluate the effect of coating drying temperature, drying time, asphalt to secondary coating mass ratio, and secondary coating type on the agglomerated count fraction at ambient temperature and $60{ }^{\circ} \mathrm{C}$. The test is able to measure a statistically significant increase in agglomeration resistance when the coating is applied, with an agglomerated fraction of $17.5 \%$ at $60{ }^{\circ} \mathrm{C}$. The test identifies asphalt to secondary coating weight ratio as a significant factor, with an ANOVA p-value much lower than other effects. A decrease in this mass ratio from 5:1 to 5:2 increases the agglomeration, which is hypothesized to be attributed to the hydrated cementitious phase between granular external surfaces. More work is needed to identify the acceptable fraction of agglomerated granules.
\end{abstract}

Keywords: agglomeration; coating; granulated Buton asphalt; two-way analysis of variance; fractional factorial experimental design.

\section{Introduction}

The demand for asphalt for civil infrastructure construction and maintenance in Indonesia has reached a volume of 1.2 million tons/year. However, mainly due to the limited capacity of existing petroleum refineries in Indonesia, domestic sources can only supply about half of the total asphalt demand [1].

The continuing decline of petroleum reserves worldwide, and the inherent instability of crude oil price, makes a strong argument for the widespread commercialization of natural asphalts. Natural asphalt is the generic term for naturally occurring, non-petroleum derived asphalt materials. These materials 
can be found in significant reserves in several countries in the world, including Indonesia.

In Indonesia, natural asphalt can be found in the Buton islands off the southeastern Sulawesi coast. According to Siswosoebrotho, et al. [2], the total reserve of the so-called Buton asphalt is estimated at no less than 120 million tons. Based on the current national demand rate, this translates to roughly a 100years supply for the domestic civil infrastructure.

The large-scale commercialization of Buton natural asphalt in Indonesia has been hampered by a number of difficulties, not the least of which is the difficulty in handling and transporting the asphalt in its as-mined, bulk form (see Figure 1). To alleviate this utilization hurdle, a number of companies in Indonesia have developed granulated form of the Buton asphalt to facilitate its transportation and handling, especially for feeding to asphalt mixing plants in construction sites nationwide.

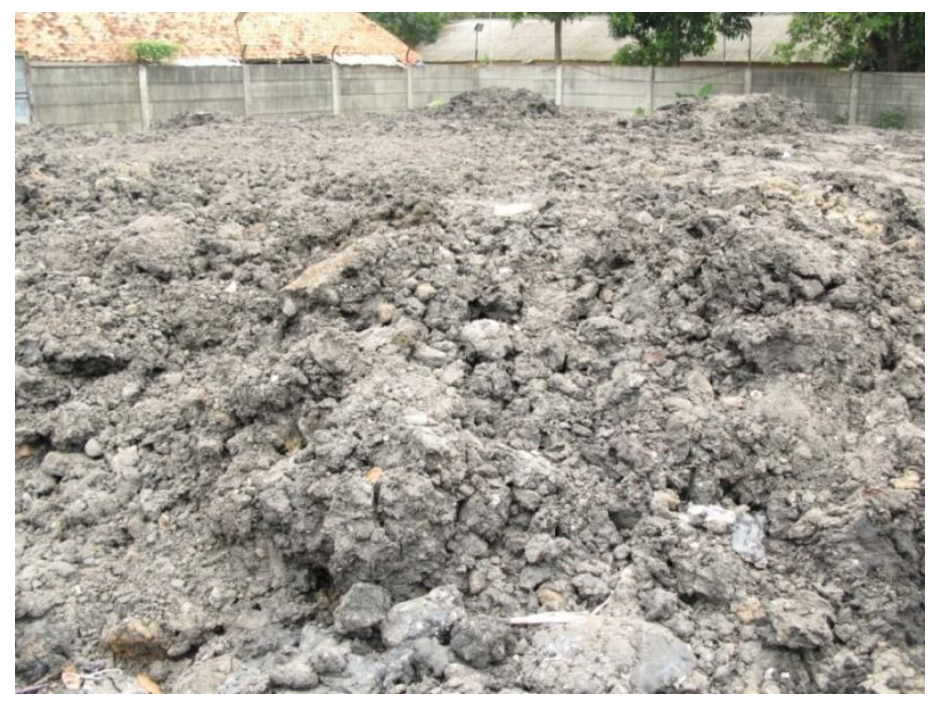

Figure 1 As-mined Buton natural asphalt.

While the granulation remains a potentially attractive solution, it has been hampered by the tendency of the asphalt granules to agglomerate during storage. This is due to the migration of the hydrocarbon phase from the interior to the external surface of the granules, which occurs when pressure is applied to the granules. High ambient temperature commonly occurring in storage warehouses in Indonesia aggravates this agglomeration or sticking tendency. 
This work is an attempt at developing a non-agglomerating coating for granulated natural asphalt which would be able to survive the condition likely to be encountered during storage. Emphasis is given on the statistical experiment design and analysis aimed at evaluating the basic approach in coating application and testing. A standard fractional factorial design is employed in the main experiment in this study. As commonly employed in the data analysis of factorial-type experiments, significance of effects measured by the experiment is quantified by the analysis of variance (ANOVA) method. This method partitions the overall variance in the experimental data into variances due to main effects (or effect of individual experimental variables), interaction effects, and random error contributions. Any significant main and/or interaction effects would exhibit variance contribution statistically higher than the variance contribution from random errors.

\section{Theoretical Background}

\subsection{General Characteristics of Buton Asphalt}

The Buton natural asphalt reserves are relatively shallow, with a minimum depth of approximately $1.5 \mathrm{~m}$. The reserves are distributed over a 70,000 hectare area from Sampolawa bay in the south to the Lawele bay in the northern side of the island. Bitumen content of this material typically varies in the 10-40 $\%$-weight range [3].

Table 1 Properties of asphalt extracted from Kabungka and Lawele natural asphalts.

\begin{tabular}{lccc}
\hline \multicolumn{1}{c}{ Properties } & Unit & $\begin{array}{c}\text { Kabungka } \\
\text { asphalt }\end{array}$ & $\begin{array}{c}\text { Lawele } \\
\text { asphalt }\end{array}$ \\
\hline Asphalt content & \%-weight & 20.0 & 30.8 \\
Penetration $\left(25^{\circ} \mathrm{C}, 100 \mathrm{~g}, 5 \mathrm{secs}\right)$ & $0.1 \mathrm{~mm}$ & 4 & 36 \\
Softening point & ${ }^{\circ} \mathrm{C}$ & 101 & 59 \\
Ductility $\left(25^{\circ} \mathrm{C}, 5 \mathrm{~cm} / \mathrm{min}\right)$ & $\mathrm{cm}$ & $<140$ & $>140$ \\
\hline Solubility in trichloroethylene & $\%$-weight & - & 99.6 \\
Flash point & ${ }^{\circ} \mathrm{C}$ & - & 198 \\
Specific gravity & & 1.046 & 1.037 \\
Loss on heating / $\mathrm{LOH}\left(16{ }^{\circ} \mathrm{C}, 5 \mathrm{hrs}\right)$ & $\%$-weight & - & 0.31 \\
Penetration after LOH $\left(25^{\circ} \mathrm{C}, 100 \mathrm{~g}, 5\right.$ & $\%$-original & - & 94 \\
secs $)$ & & & 62 \\
Softening point after $\mathrm{LOH}$ & ${ }^{\circ} \mathrm{C}$ & - & \\
\hline
\end{tabular}

Two general types of Buton asphalt has been recognized. The Kabungka-type asphalt is a relatively hard material consisting mainly of limestone (85\%weight), with a penetration number of 5-10. Bitumen content of Kabungka-type 
asphalt varies in the $10-25 \%$-weight range. The Lawele-type asphalt is substantially softer, darker in color, and consists mainly of silica sand $(49.5 \%$ weight). The penetration number of Lawele-type asphalt is 32 to 200, with a bitumen content of 20 to $35 \%$-weight $[2,4]$.

In general, both Kabungka- and Lawele-type asphalts are considered to exhibit good properties for pavement construction. The bituminous materials provided by these natural minerals exhibit relatively low penetration number and high asphaltene content. Table 1 outlines the properties of asphalt extracted by solvent from Kabungka and Lawele natural asphalts measured by Siswosoebrotho, et al. [2].

\subsection{Current Exploitation and Production of Buton Asphalt}

The Kabungka and Lawele asphalts are exploited in a different manner. The Kabungka asphalt is exploited by stripping and blasting, followed by size reduction to 0.5 inches, drying, and fine milling to a maximum granule size of 4-mesh. The Lawele asphalt, on the other hand, is exploited by stripping and excavation, without blasting and size reduction.

Processing of the recovered Buton asphalt typically involves the following steps (Kurniaji [5]):

1. Communution and classification

This step is designed to obtain particle size distribution that completely passes 16-mesh, and 30-40\% of which passes through a 200-mesh sieve.

2. Heating to reduce moisture and volatile hydrocarbon content

Moisture content of as-received Buton asphalt may range from 15 ro 20\%weight, while the volatile hydrocarbon content ranges from 5.4 to $8.7 \%$ weight. Moisture and volatile hydrocarbon contents need to be reduced by heating, to obtain a loss-on-heating $(\mathrm{LOH})$ at $163{ }^{\circ} \mathrm{C}$ and 5 hours of not more than $2 \%$-weight. In practice, reduction of moisture and volatile hydrocarbon is achieved by heating the asphalt at $120{ }^{\circ} \mathrm{C}$ with continuous turning to avoid overheating and localized coking.

\section{$3 \quad$ Methodology}

The coating employed in this study consists of two layers, an inner layer (or primary coating) and an outer layer (or secondary coating). The primary coating is carbohydrate-based, while the secondary coating consists of inorganic powders. The selection of the water/oil affinity of the primary and secondary coatings is based on the concept that the primary coating should be able to 
confine the bituminous phase within the pores of the granules, while the secondary coating serves to bind any residual moisture at the external surface of the granules, thereby preventing the hydrophilic primary coating from being rehydrated.

The primary coating is first applied by spraying the water-soluble carbohydratebased coating at a concentration of $2 \%$-weight into a rotating open tank containing the asphalt granules. For every gram of dry granules, approximately $0.2 \mathrm{~mL}$ coating suspension is sprayed.

After the granules have been coated with the primary coating, the secondary coating is fed into the rotating tank while the primary coating is still moist. The entire mixture is tumbled for 5 minutes to ensure an even coating before being taken out and dried in an electric oven at the prescribed temperature.

At this particular stage of the study, it is desired to identify key process variables influencing the performance of the non-stick coating. Since the focus of the experiment is to identify main effects, a half-factorial 2-level (or $2^{\mathrm{k}-1}$ ) experiment is selected to study the effect of coating process variables: coating drying temperature $\left(\mathrm{x}_{1}\right)$, drying time $\left(\mathrm{x}_{2}\right)$, asphalt to coating mass ratio $\left(\mathrm{x}_{3}\right)$, and type of coating $\left(\mathrm{x}_{4}\right)$. For this relatively small number of factors, a $2^{\mathrm{k}-1}$ is considered sufficiently accurate to identify significant factors, without involving a large number of runs [6]. The design generator selected for the $2^{4-1}$ design is $\mathrm{x}_{4}$ $=-\mathrm{x}_{1} \mathrm{X}_{2} \mathrm{X}_{3}$, which means that the factor level setting of $\mathrm{x}_{4}$ is equal to the minus of the multiplication of the other three factors. To obtain an estimate of the experimental precision, two replicates are run for each experimental condition $(\mathrm{n}=2)$.

Table 2 presents the actual values of the factors. Low and high levels of these values are selected based on preliminary runs. Inorganic materials selected for the secondary coating are coal bottom ash and coal fly ash. Table 3 presents the analysis of these coal ashes. The bottom ash was obtained from a textile manufacturing plant in the Bandung area, while the fly ash was obtained from a major coal-fired electric power plant in the Paiton area in East Java. The high residual carbon content in the bottom ash is particularly notable in Table 3.

It should be noted that the experimental design consists of three quantitative factors $\left(\mathrm{x}_{1}, \mathrm{x}_{2}\right.$, and $\left.\mathrm{x}_{3}\right)$ and one categorical factor $\left(\mathrm{x}_{4}\right)$. Any empirical regression model derived from the experiment would therefore at most involve three quantitative factors. Figure 2 is a schematic representation of the experimental design. 
The analysis of data generated by the $2^{4-1}$ experiment follows the standard method of ANOVA or analysis of variance. Exhaustive discussions on this method are available in most standard textbooks on statistical experimental design and analysis, such as the classic text by Montgomery [6]. Interested readers are encouraged to peruse this excellent reference.

Table 2 Actual values of experimental factors.

\begin{tabular}{|c|c|c|}
\hline Factor & Notation & Values \\
\hline drying temperature & $\mathrm{X}_{1}$ & $\begin{array}{l}\text { low }=32{ }^{\circ} \mathrm{C} \\
\text { high }=60^{\circ} \mathrm{C}\end{array}$ \\
\hline drying time & $\mathrm{X}_{2}$ & $\begin{aligned} \text { low } & =5 \text { minutes } \\
\text { high } & =30 \text { minutes }\end{aligned}$ \\
\hline $\begin{array}{c}\text { asphalt : secondary coating } \\
\text { mass ratio }\end{array}$ & $\mathrm{X}_{3}$ & $\begin{array}{l}\text { low }=5 / 2 \\
\text { high }=5 / 1\end{array}$ \\
\hline secondary coating type & $\mathrm{X}_{4}$ & $\begin{array}{c}\text { low = bottom ash } \\
\text { high = fly ash }\end{array}$ \\
\hline
\end{tabular}

Table 3 Analysis of coal bottom and fly ashes used as secondary coating materials.

\begin{tabular}{|c|c|}
\hline \multicolumn{2}{|c|}{ Bottom ash } \\
\hline Parameters & Values (as-received) \\
\hline Moisture & $0.7 \%$ \\
\hline Ash content & $54.2 \%$ \\
\hline Volatile matter (VM) & $8.71 \%$ \\
\hline Fixed carbon (FC) & $36.39 \%$ \\
\hline HHV & $3324 \mathrm{cal} / \mathrm{g}$ \\
\hline Sulfur (S) & $0.35 \%$ \\
\hline Carbon (C) & $39.64 \%$ \\
\hline Hydrogen $(\mathrm{H})$ & $1.1 \%$ \\
\hline Loss on ignition (LOI) & $40.8 \%$ \\
\hline \multicolumn{2}{|c|}{ Fly ash } \\
\hline Oxide component & $\%$-weight \\
\hline $\mathrm{SiO}_{2}$ & 45.6 \\
\hline $\mathrm{Al}_{2} \mathrm{O}_{3}$ & 35.0 \\
\hline $\mathrm{Fe}_{2} \mathrm{O}_{3}$ & 11.77 \\
\hline $\mathrm{CaO}$ & 0.203 \\
\hline $\mathrm{MgO}$ & 1.721 \\
\hline $\mathrm{Na}_{2} \mathrm{O}$ & 0.611 \\
\hline $\mathrm{K}_{2} \mathrm{O}$ & 1.231 \\
\hline $\mathrm{TiO}_{2}$ & 1.0 \\
\hline $\mathrm{SO}_{3}$ & 0.5 \\
\hline $\mathrm{P}_{2} \mathrm{O}_{5}$ & 0.5 \\
\hline Loss on ignition & 0.64 \\
\hline
\end{tabular}


It is sufficient to briefly outline here that the basic approach in ANOVA involves the partitioning of the overall experimental variance into contributions from main effects (effects associated with individual experimental factors), interaction effects (effects associated with the simultaneous change of 2 or more factors), and random errors (which reflect the precision of the experiment). By performing F-tests, comparisons are made between each of the variance contributed by these effects and that contributed by the random errors.

For each effect, the P-value is computed which reflects the significance of the respective effect. Higher P-value indicates a lower statistical significance of the effect. Traditional values of probability or significance levels have been widely used as references to judge the significance of an effect based on its P-value. Pvalues lower than these significance levels $(0.50$ or 0.10 are popular values of significance levels) indicate the significance of the respective effect. The use of these reference significance levels is not to be construed as restrictive, however, and should rather be viewed as rather loose guideline for interpreting the Pvalues obtained in an experiment.

Data analysis and construction of graphs from the experimental data are undertaken using the Microsoft Excel ${ }^{\mathrm{TM}} 2007$ package.

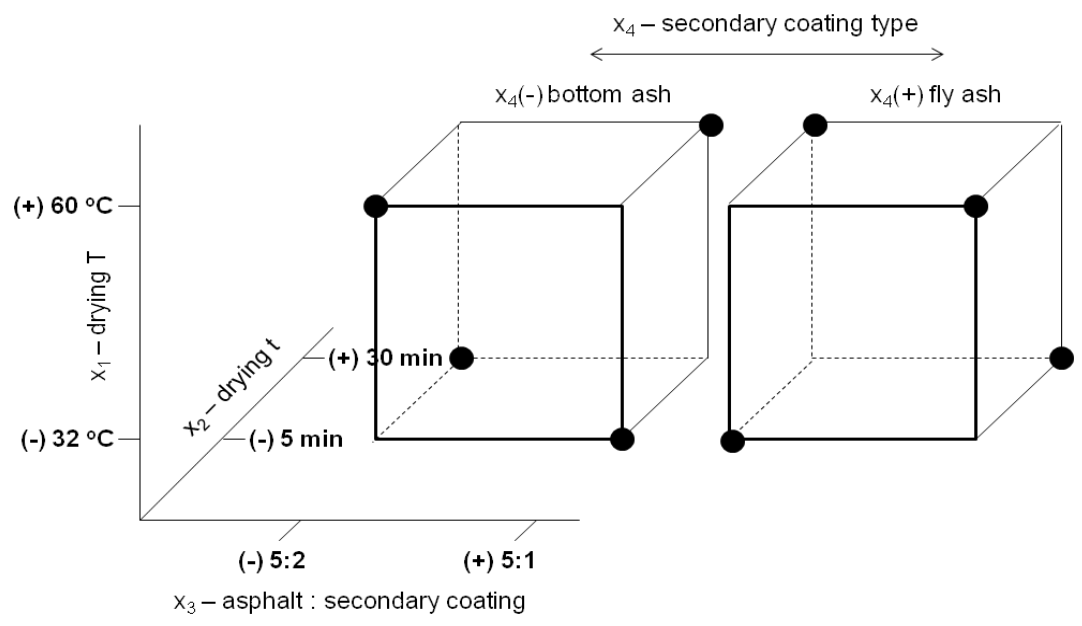

Figure 2 The $2^{4-1}$ fractional factorial design used in this study.

Currently, no technical standard exists for the evaluation of granulated natural asphalt products. In order to fulfill the need for practical performance evaluation methods, several simple testing methods have been developed to evaluate the relative performance of coatings. These methods are designed to emulate worst 
pressure and temperature conditions likely to exist during the storage of granulated natural asphalt products.

This test uses a simple custom-made uniaxial loading cell, as presented in Figure 3. This apparatus consists of a cast iron cylinder $(40 \mathrm{~mm}$ internal diameter x $100 \mathrm{~mm}$ long), closed on one end and open on the other end, which holds the sample granules, and a solid cast iron cylindrical rod which applies pressure to the sample inside the cylindrical holder. A flat circular steel plate is welded on to the end of the rod to enable the placement of additional deadweights. Figure 3 presents the photograph of this test cell.

In the test, sample granules are inserted into the hollow cylinder holder which is then positioned vertically. The solid loading rod is then inserted into the filled cylinder, and the entire assembly is left to stand for 60 minutes. Additional deadweights are added to the rod so that the combined weight of the solid rod and deadweights is equivalent to the load exerted by a $2 \mathrm{~m}$ high stack of standard-sized product bags, which is the commonly practiced limit of stacking height in warehouses.

The agglomeration test is undertaken at two temperatures: (1) at room temperature, to obtain the baseline performance of the coatings, and (2) at 60 ${ }^{\circ} \mathrm{C}$, representing the worst-case product storage conditions in Indonesia.
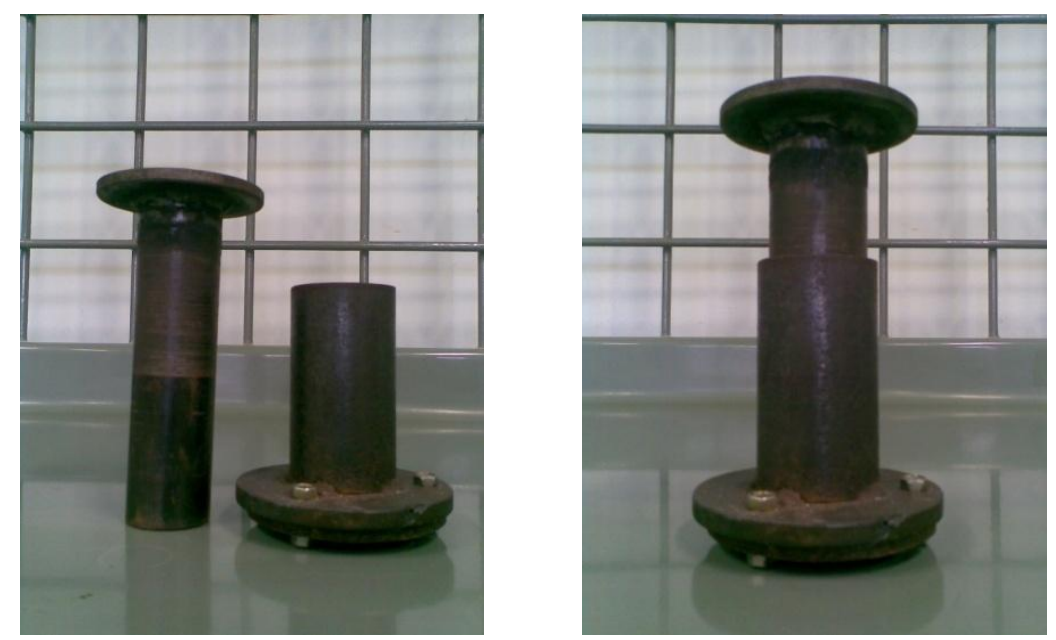

Figure 3 Uniaxial static loading cell for the agglomeration testing of asphalt granules. 


\section{$4 \quad$ Results and Discussion}

Table 4 compiles all key measurement data obtained from the $2^{4-1}$ experiment. For the room temperature agglomerated fraction response $\left(\mathrm{y}_{1}\right)$, the lowest average is $6.43 \%\left(x_{1}=-, x_{2}=+, x_{3}=+, x_{4}=+\right)$, and the highest average is 33.57 $\%\left(\mathrm{x}_{1}=-, \mathrm{x}_{2}=+, \mathrm{x}_{3}=-, \mathrm{x}_{4}=-\right)$. For the elevated temperature agglomerated fraction $\left(\mathrm{y}_{2}\right)$, the lowest average is $20.18 \%\left(\mathrm{x}_{1}=-, \mathrm{x}_{2}=+, \mathrm{x}_{3}=+, \mathrm{x}_{4}=+\right)$, and the highest average is $59.49 \%\left(x_{1}=-, x_{2}=-, x_{3}=-, x_{4}=+\right)$. As a comparison, the agglomerated fraction of uncoated granulated asphalt is $100 \%$ at both room and elevated temperatures.

The following discussion reviews the statistical data analysis of each response variable, i.e. room temperature and elevated temperature agglomeration measurement using the static loading cell apparatus.

Table 4 Results from the $2^{4-1}$ experiment $(\mathrm{n}=2)$ for measuring the ambient temperature $\left(\mathrm{y}_{1}\right)$ and high temperature $\left(\mathrm{y}_{2}\right)$ agglomeration of coated Buton asphalt granules.

\begin{tabular}{ccccccc}
\hline $\begin{array}{c}\text { Actual run } \\
\text { order }\end{array}$ & $\mathbf{x}_{\mathbf{1}}$ & $\mathbf{x}_{\mathbf{2}}$ & $\mathbf{x}_{\mathbf{3}}$ & $\mathbf{x}_{\mathbf{4}}$ & $\mathbf{y}_{\mathbf{1}}, \boldsymbol{\%}$ & $\mathbf{y}_{\mathbf{2}}, \boldsymbol{\%}$ \\
\hline 1 & + & - & - & - & 29.75 & 42.92 \\
2 & + & - & + & + & 9.27 & 33.33 \\
3 & + & + & - & + & 39.61 & 36.82 \\
4 & - & + & - & - & 42.14 & 72.61 \\
5 & - & - & - & + & 33.50 & 78.57 \\
6 & + & + & + & - & 26.09 & 40.32 \\
7 & - & + & - & - & 25.00 & 37.59 \\
8 & - & + & + & + & 7.10 & 13.91 \\
9 & + & - & + & + & 5.59 & 17.52 \\
10 & + & + & + & - & 21.91 & 27.33 \\
11 & - & - & + & - & 16.67 & 35.95 \\
12 & - & - & - & + & 17.99 & 40.41 \\
13 & + & + & - & + & 16.35 & 25.58 \\
14 & + & - & - & - & 25.50 & 28.67 \\
15 & - & + & + & + & 5.76 & 26.44 \\
16 & - & - & + & - & 27.61 & 21.69 \\
\hline
\end{tabular}

\subsection{Ambient Temperature Agglomeration Test}

First, a second-order analysis of variance (ANOVA) of the experimental data is undertaken at a significance level $\alpha=0.05$ to identify significant main effects and two-way interactions. The results are presented as a Pareto plot in Figure 4 and as an ANOVA table in Table 5. The critical line for normal behavior using $\alpha=0.05$ (equivalent to a standardized effect of 2.306) is included in the Pareto plot. 
Based on the $\mathrm{p}$-values of all main effects and two-way interactions, $\mathrm{x}_{3}$ (asphalt to secondary coating mass ratio) is likely to be a significant factor in determining the ambient temperature agglomeration. Significance judgment for $\mathrm{x}_{4}$ (secondary coating type) is not as clear-cut as $\mathrm{x}_{3}$, since its p-value is just a little higher than 0.05 selected as the significance level of this data analysis. In order to preserve as many significant terms as possible, $\mathrm{x}_{4}$ is included in the next analysis step.

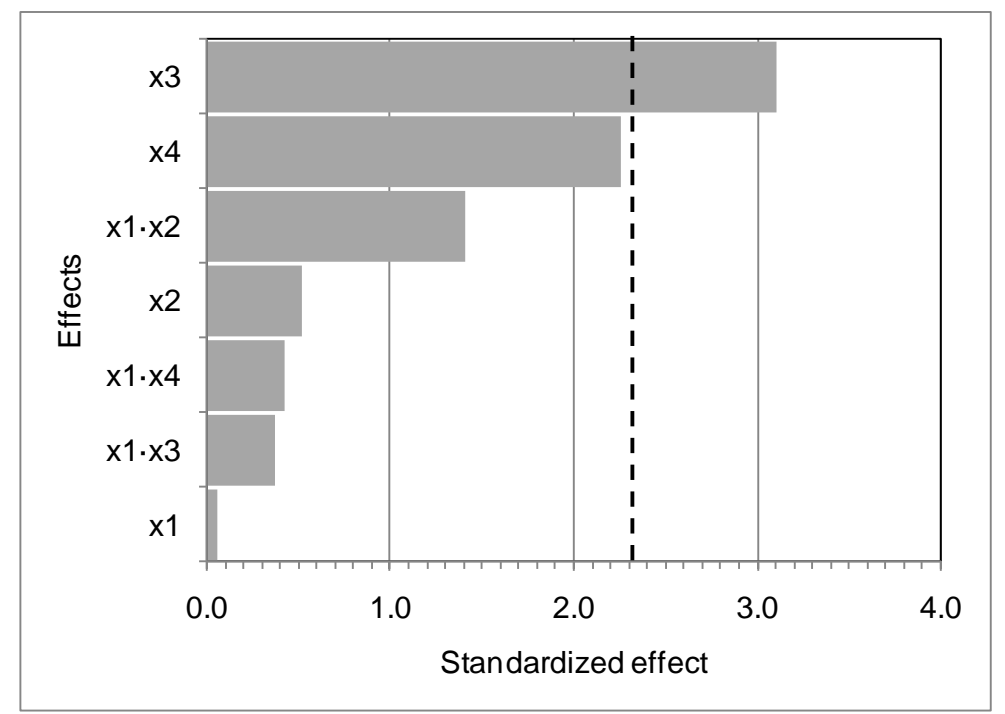

Figure 4 Pareto plot of standardized effects for the room temperature agglomeration test, obtained from $2^{\text {nd }}$-order ANOVA.

A refined model is then constructed, involving only the $x_{3}$ and $x_{4}$ main effects. Table 6 presents the ANOVA results for the refined model involving only $\mathrm{x}_{3}$ and $\mathrm{x}_{4}$ main effects. $\mathrm{P}$-values of both main effects confirm their significance. To evaluate the validity of ANOVA model assumptions, standardized residual plots associated with the refined model are presented in Figure 5.

The normality assumption for ANOVA reasonably holds, as suggested by Figure 5.a. However, the S-like shape of the normal plot of residuals also suggests that nuisance factors may also influence the results. At this stage of the study, this nuisance factor(s) is not yet identified. The assumption of independent residuals also holds, as suggested by the lack of any pattern in the residuals vs. actual run order plot (Figure 5.b). 
Table 5 Significance of effects and ANOVA table for the room temperature agglomerated fraction measurement.

(a) Significance of effects

\begin{tabular}{crrrl}
\hline Term & Effect & Coefficient & \multicolumn{1}{l}{ T } & P \\
\hline Constant & & 21.865 & 9.91 & 0.000 \\
$\mathrm{x}_{1}$ & -0.212 & -0.106 & -0.05 & 0.963 \\
$\mathrm{x}_{2}$ & 2.260 & 1.130 & 0.51 & 0.622 \\
$\mathrm{X}_{3}$ & -13.730 & -6.865 & -3.11 & 0.014 \\
$\mathrm{x}_{4}$ & -9.938 & -4.969 & -2.25 & 0.054 \\
$\mathrm{x}_{1} \cdot \mathrm{x}_{2}$ & 6.203 & 3.101 & 1.41 & 0.197 \\
$\mathrm{x}_{1} \cdot \mathrm{x}_{3}$ & 1.643 & 0.821 & 0.37 & 0.719 \\
$\mathrm{x}_{1} \cdot \mathrm{x}_{4}$ & 1.830 & 0.915 & 0.41 & 0.689 \\
\hline
\end{tabular}

(b) ANOVA table

\begin{tabular}{lcrrrr}
\hline \multicolumn{1}{c}{ Source } & $\begin{array}{c}\text { Degree of } \\
\text { freedom }\end{array}$ & $\begin{array}{c}\text { Sum of } \\
\text { squares }\end{array}$ & \multicolumn{1}{c}{$\begin{array}{c}\text { Mean } \\
\text { squares }\end{array}$} & F & P \\
\hline Main effects & 4 & 1169.68 & 292.42 & 3.76 & 0.053 \\
2-way interactions & 3 & 178.07 & 59.36 & 0.76 & 0.546 \\
Residual error & 8 & 622.96 & 77.87 & & \\
\hline Total & 15 & 1970.71 & & & \\
\hline
\end{tabular}

Table 6 ANOVA results of the refined model for room temperature agglomerated fraction measurement

(a) Estimated effects

\begin{tabular}{lrrrl}
\hline \multicolumn{1}{c}{ Term } & Effect & Coefficient & \multicolumn{1}{c}{ T } & P \\
\hline Constant & & 21.865 & 11.00 & 0.000 \\
$\mathrm{x}_{3}$ & -13.730 & -6.865 & -3.45 & 0.004 \\
$\mathrm{x}_{4}$ & -9.937 & -4.969 & -2.50 & 0.027 \\
\hline
\end{tabular}

(b) ANOVA table

\begin{tabular}{lcrrrr}
\hline Source & $\begin{array}{c}\text { Degree of } \\
\text { freedom }\end{array}$ & $\begin{array}{c}\text { Sum of } \\
\text { squares }\end{array}$ & $\begin{array}{c}\text { Mean } \\
\text { squares }\end{array}$ & F & P \\
\hline Main effects & 2 & 1149.2 & 574.53 & 9.09 & 0.003 \\
Residual error & 13 & 821.6 & 63.20 & & \\
\hline Total & 15 & 1970.7 & & & \\
\hline
\end{tabular}

The final step in the data analysis is the construction of an empirical regression model representing an explicit relationship between the fraction of agglomerated granules at ambient temperature to the significant experimental factors. Since $x_{4}$ is a categorical (qualitative) factor, the explicit regression model can only contain $\mathrm{x}_{3}$ as the independent variable:

$$
\text { Room T agglomeration }(\%)=21.865-6.865 \mathrm{x}_{3}
$$


The coefficient for $\mathrm{x}_{3}$ is negative, indicating that higher asphalt to secondary coating mass ratio tends to decrease the agglomeration of the asphalt granules. To explain this counterintuitive behavior, it is hypothesized that at an asphalt : coating mass ratio of 5:2, hydration of the secondary coating by the moisture in the ambient atmosphere creates bridging between the coated granules. It is therefore hypothesized further that the amount of secondary coating has to be sufficient to evenly coat the surface of the granules, but not too much so as to create a polymeric bridging between the surfaces of adjacent granules upon hydration by the ambient moisture.

The feasibility of using the very simple uniaxial static loading cell apparatus to study the agglomeration behavior of granulated natural asphalt is reflected by its ability to identify factors which significantly impacts the agglomeration behavior of the granules. As indicated in Table 5.a, the p-value of $x_{3}$ and $x_{4}$ main effects are substantially lower than that of the other effects.

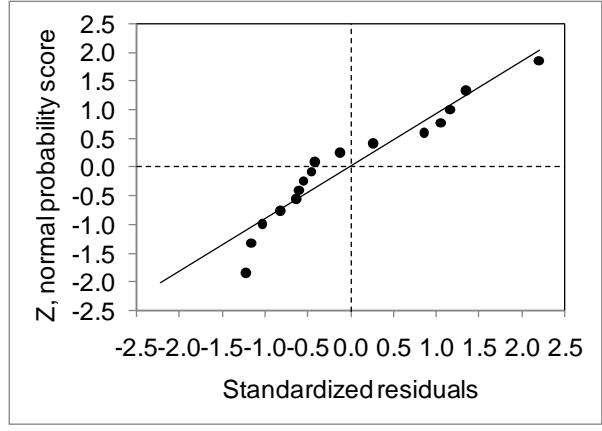

(a)

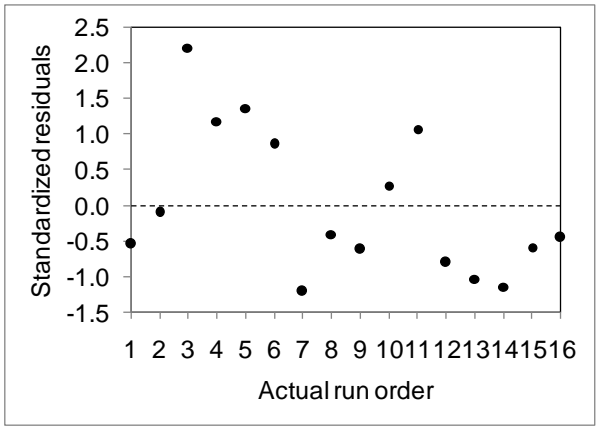

(b)

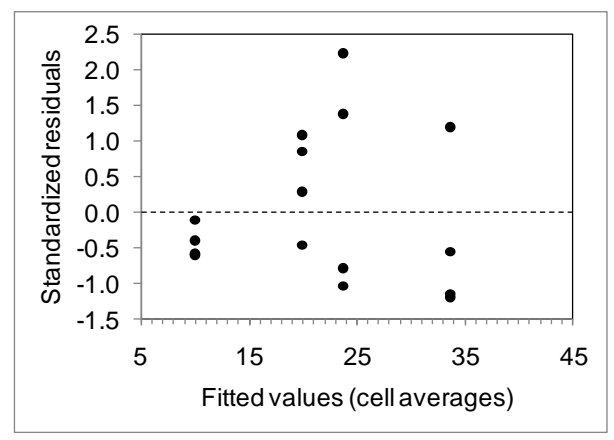

(c)

Figure 5 Residual analysis of the refined ANOVA model of ambient temperature agglomeration. (a) normal probability plot of residuals (b) residuals vs. actual run order (c) residuals vs. fitted values. 


\subsection{Elevated Temperature Agglomeration Test}

Estimated effects obtained from a full-model ANOVA of the elevated temperature agglomeration data are presented in Table 7. A somewhat different behavior is observed compared to the room temperature agglomeration measurement, in that the only significant main effect is the asphalt to secondary coating mass ratio. However, a rather mild interaction is also observed in Table 7 , namely the (drying temperature) $\cdot\left(\right.$ asphalt:coating mass ratio) or $\mathrm{x}_{1} \cdot \mathrm{x}_{3}$ interaction.

The large difference in the p-value of $x_{3}$ to those of the other main effects and two-way interactions suggests the feasibility of the static uniaxial loading test for evaluating the process variables controlling the agglomeration behavior of granulated natural asphalt at elevated ambient temperatures, and as a compact, easy to use field testing method for granulated natural asphalt products.

A refined-model ANOVA is subsequently run, incorporating only $x_{1}$ and $x_{3}$ main effects, and $x_{1} \cdot x_{3}$ interaction. The $x_{1}$ main effect is retained in accordance with the hierarchy principle in regression model building [6]. Table 8 presents the estimated effects and ANOVA table of this refined model, which is represented by the following regression equation:

High T agglomeration $(\%)=36.229-4.667 \mathrm{x}_{1}-9.168 \mathrm{x}_{3}+7.231 \mathrm{x}_{1} \mathrm{x}_{3}$

Table 7 Significance of estimated effects for elevated temperature agglomerated fraction measurement

\begin{tabular}{lrrl}
\hline \multicolumn{1}{c}{ Term } & \multicolumn{1}{c}{ Effect } & Coefficient & P \\
\hline Constant & & 36.229 & 0.000 \\
$\mathrm{x}_{1}$ & -9.335 & -4.667 & 0.260 \\
$\mathrm{x}_{2}$ & -2.307 & -1.154 & 0.772 \\
$\mathrm{x}_{3}$ & -18.335 & -9.168 & 0.044 \\
$\mathrm{x}_{4}$ & -4.313 & -2.156 & 0.591 \\
$\mathrm{x}_{1} \cdot \mathrm{x}_{2}$ & 4.210 & 2.105 & 0.599 \\
$\mathrm{x}_{1} \cdot \mathrm{x}_{3}$ & 14.463 & 7.231 & 0.097 \\
$\mathrm{x}_{1} \cdot \mathrm{x}_{4}$ & -2.185 & -1.092 & 0.784 \\
\hline
\end{tabular}

Analogous to the analysis of the ambient temperature agglomeration data, the validity of assumptions taken in the ANOVA treatment of experimental data (i.e. that the residuals are normally and independently distributed with a mean of zero and variance $\sigma^{2}$ ) is checked by constructing plots of standardized residuals. These are presented in Figure 6. The normal probability plot of residuals and plot of residuals vs. actual run order suggest that the normality and independence of residuals assumptions are justified. The residuals vs. fitted values suggest some degree of non-constancy of the variance. Again, this is not 
deemed to be critical since the F-test employed in ANOVA is relatively robust to non-constant variance [6].

Table 8 ANOVA using the refined model for the high temperature agglomeration test results.

(a) Significance of estimated effects.

\begin{tabular}{lccc}
\hline \multicolumn{1}{c}{ Term } & Effect & Coefficient & P-value \\
\hline Constant & & 36.229 & 0.000 \\
$\mathrm{x}_{1}$ & -9.335 & -4.667 & 0.182 \\
$\mathrm{x}_{3}$ & -18.335 & -9.168 & 0.017 \\
$\mathrm{x}_{1} \cdot \mathrm{x}_{3}$ & 14.462 & 7.231 & 0.048 \\
\hline
\end{tabular}

(b) ANOVA table

\begin{tabular}{lcrrrr}
\hline \multicolumn{1}{c}{ Source } & $\begin{array}{c}\text { Degree of } \\
\text { freedom }\end{array}$ & $\begin{array}{c}\text { Sum of } \\
\text { squares }\end{array}$ & $\begin{array}{c}\text { Mean } \\
\text { squares }\end{array}$ & $\mathbf{F}_{\mathbf{0}}$ & $\begin{array}{c}\text { P- } \\
\text { value }\end{array}$ \\
\hline Main effects & 2 & 1693.3 & 846.6 & 4.88 & 0.028 \\
2-way interactions & 1 & 836.7 & 836.7 & 4.82 & 0.048 \\
Residual error & 12 & 2081.2 & 173.4 & & \\
\hline Total & 15 & 4611.1 & & & \\
\hline
\end{tabular}

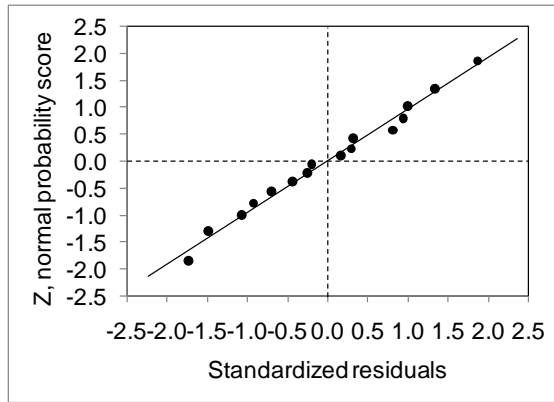

(a)

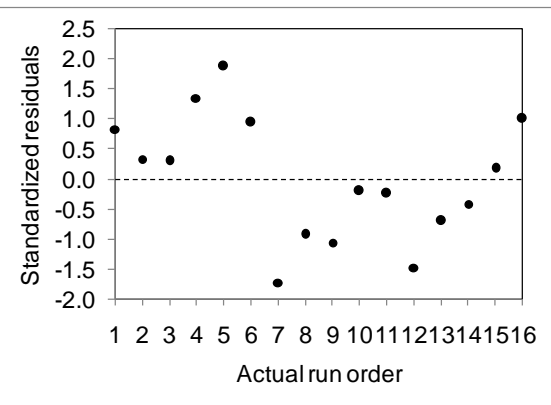

(b)

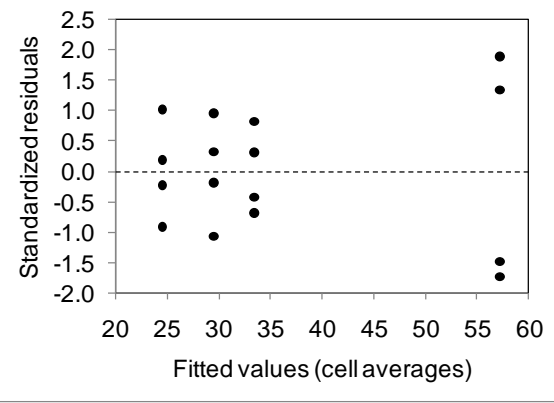

(c)

Figure 6 Residual analysis of the refined ANOVA model of elevated temperature agglomeration. (a) normal probability plot of residuals (b) residuals vs. actual run order (c) residuals vs. fitted values. 
The ANOVA table of the refined model indicates that, although the drying temperature main effect is not significant, its interaction with asphalt to coating mass ratio is. However, the p-value of this interaction term is very close to the commonly adopted significance level of $\alpha=0.05$. Further measurements are likely to be needed to confirm the significance (or insignificance) of the $\mathrm{x}_{1} \cdot \mathrm{x}_{3}$ interaction. Keeping in mind that the main goal of this particular stage of the study is to identify key main effects influencing the agglomeration tendency of the granulated natural asphalt, the uncertainty associated with the addition of the interaction term in the empirical regression model is not viewed as critical.

\section{$5 \quad$ Conclusions and Recommendations}

The uniaxial static loading test cell has suggested promising results in identifying key process variables controlling the non-stick coating for granulated Buton natural asphalt, and has demonstrated its potential as a compact, easy to use field test apparatus for the quality control of granulated asphalt products.

The asphalt to secondary coating mass ratio is consistently identified as the key variable in controlling the agglomeration behavior at both ambient and elevated temperatures. Statistical significance of this factor is substantially higher than other main effects and interaction effects in both ambient and elevated temperature agglomeration measurements.

Within the range of variation considered in this study (5:2 to 5:1), agglomeration may be minimized by keeping the asphalt to coating mass ratio low. At high mass ratio, it is hypothesized that hydration of the dry secondary coating materials by the ambient moisture forms polymeric intergranular bridging.

While an obvious improvement in agglomeration resistance of the coated versus uncoated granulated Buton asphalt has been observed, further verification still needs to be undertaken to define the maximum fraction of agglomerated granule count that can still be tolerated. The lowest agglomerated count fraction observed in this work is $17.5 \%$; it is still yet to be proven whether this value is satisfactory or not.

\section{Acknowledgments}

The authors wish to thank PT Reka Konsultama for supporting the initial development efforts of the granulated Buton asphalt coating. The major part of research work presented in this paper was supported by the ITB Research Group Grant 2010 (Hibah Riset Kelompok Keahlian ITB 2010). 


\section{References}

[1] Soeroso, B., Utilization of Buton Asphalt for Road Construction in Indonesia (in Indonesian), Proceedings of Buton Asphalt Technology Workshop, Department of Public Works Research and Development Center, 21 November 2006.

[2] Siswosoebrotho, B.I., Kusnianti, N. \& Tumewu, W., Laboratory Evaluation of Lawele Buton Natural Asphalt in Asphalt Concrete Mixture (in Indonesian), Proceedings of the Eastern Asia Society for Transportation Studies, 5, pp.857-867, 2005,

[3] Asrun, Buton Asphalt (in Indonesian), Southeast Sulawesi Public Works Service, 1999, http://sultra.tripod.com/ASPAL_BUTON.htm (Accessed on 26 March 2010)

[4] Hardjosukanto, S., Lawele Buton Asphalt: its Difference from Kabungka Buton Asphalt, Conditioning, and Application in Asphalt Mixes (in Indonesian), Majalah Teknik Jalan dan Transportasi, 104, pp.16-20, 2004.

[5] Kurniaji, Application of Buton Lake Asphalt in Asphalt Hot Mixes (in Indonesian), Transportation Infrastructure Research and Development Center Report, Department of Public Works, 2002.

[6] Montgomery, D.C., Design and Analysis of Experiments, 5th edition, John Wiley and Sons, Singapore, 2001. 